\title{
DIAGNOSTIC MANAGEMENT - METHOD OF INCREASING THE POTENTIAL OF RESEARCH AND DEVELOPMENT STATION FOR CATTLE FROM ARAD
}

\author{
Silviu Ilie SĂPLĂCAN, Ramona LILE \\ "Aurel Vlaicu" University of Arad, Romania \\ silviusaplacan@yahoo.com
}

\begin{abstract}
Research and Development Station for Cattle Arad is a public institution of national interest and its main activity is research and development in biotechnology and livestock breeding. The purpose of this paper is to analyze and improve through recommendations, the management applied on the livestock-breeding farm from the station. We are showing at first glance, the following important aspects: methods and techniques used by senior management and livestock at the farm are not up-to-date both morally and technology, which are also partly used. The station has a hierarchical - functional organizational, but nevertheless, the information system is underdeveloped. Also using such authoritarian management style promotes cooperation resort management, consulting and delegation between the chambers, but in a way inefficient. The role and the performance of the management system of the breeding farm is a decisional component with a privileged role. No other element of the resort management has a specificity so obvious and so great of an impact on all plans and performance results. The strengths and weaknesses of an institution of this kind are described in the literature that we use to test, draw and make recommendations for the future growth potential of the station, both in terms of managerial, economic -financial and in terms of the quality of work processes and finished products. To achieve a practical study, we present the relevant results after applying the latest technology management, reporting and decision-making for some time on senior management, livestock breeding management and on cooperation between these compartments.
\end{abstract}

Keywords: management, potential, increasing, farm, cattle

\section{Introduction}

The Research and Development Station for Cattle from Arad is a public institution with funding from the state budget (category 01 ), the source coming from own revenues and subsidies from the state budget (Category $\mathrm{G})$. Considering that in reality subsidies from the state budget from authorizing senior officers have been missing in recent years thus financial resources being scarce, concern for increasing organizational efficiency and effectiveness becomes increasingly obvious. Trying to improve the management applied in farm livestock alongside with superior management should lead to a rise in productivity in terms of efficient resource consumption with the result being the fulfillment of the purpose of the result that is creating a genuine national race, enhanced by genetics and certified by authorized entities.

This use of various technical and technological means in order to achieve the objectives, planned in stages in order to achieve the final goal in optimum efficiency, defines what we call organizational management and its diagnosis[1] [2].

The applied management of the resort refers to features such as future strategies, chosen management model, hierarchy management, ethics and integrity management or communication in order to identify weaknesses in the management of 
applied processes inside the breeding farm. We will also address issues regarding process management to identify the characteristics applied to the resort and that might prove useful to public institutions of this kind in Romania and in all private entities related to livestock farms[3].

\section{Methodology and data}

The methodology used to conduct this research work were the study of specialized literature and analyzing information provided by the station. We also used tools and techniques specific for qualitative research, analysis of internal documents, economic records and discussions with the managers of the resort. Also used were comparative analysis and synthesis, all of which are useful in interpreting the results.

The structure, organization components and the relations between them [4], in the station are hierarchical - functional, involving the use of human resources and allocating responsibility for managing the results. In this case, these processes were determined to be obsolete from all points of view. Document bureaucracy for equipping the breeding farm and everyday expenses regarding activity greatly slowed down all management processes[5] [6], employees are unable to carry out its activities according to the job description and above all and they don't respect the work program correctly.

Following these different findings, we proceeded to implementation during the $2^{\text {nd }}$ quarter of 2016 of only three modern systems of management implementation of other such systems will be subject of future studies. We implemented as beta-testing, a new electronic system (SVTech) of work clocking and employee check, where a magnetic card is assigned to each employee personally to check in on whether the employee is following the working program thus the farm manager is encumbered to present various reports on the work of employees so that they are paid correctly. A $2^{\text {nd }}$ management system was to create a table made in Microsoft Office Excel which was then added on the livestock farm manager's PC, table predefined with cell block for generating documents in Microsoft Office Word by using the tool step-by-step mail merge wizard, necessary for acquisition of various materials required, thereby allowing them to focus on farm business management and not preparing various statistical documentation. The $3^{\text {rd }}$ system implemented was the use of electronic signatures in the form of tokens for documents created in Microsoft Office Word and then converted to PDF file format and sending them via mailbox (email) to people employed by the authorizing higher in rank person responsible for loans to be able to assess the different expenses needed to be made, to view and approve them, and after their approval sending the data to staff in charge of the supply department in order to follow the necessary steps to acquire them.

\section{Research results}

Following the simplification of the management processes described and applied on The Research and Development Station for Cattle from Arad [7] inside the breeding farm department, relationships between employees, subordinates and senior management was improved, resource allocation time dropped from 2 to 3 days to 2 to 3 hours. For example, drugs should be procured urgently and had a precedent of not being paid due to non-compliance with all the procedures. Finished product quality and processes necessary for their finalization have been improved. Total expenditure of the livestock sector of the resort reached a real and optimal level in the $2^{\text {nd }}$ quarter of 2016 amounting to 238,000 lei when the systems mentioned above have been implemented as opposed to the $1^{\text {st }}$ quarter of 2016 when they were 253,000 lei. Revenues from the $2^{\text {nd }}$ quarter of the breeding farm increased by $4 \%$ from 723,000 lei in the $1^{\text {st }}$ quarter of 2016 to 752,000 lei in the $2^{\text {nd }}$ quarter of 2016 . From 
a zootechnical point of view, these measures also led to an increase in livestock, the number of calves that died at birth being reduced by $7 \%$ due to the increasing concern of the zootechnical manager upon the different treatments applied to livestock animals. With the help of the implemented systems mentioned above and the more thorough made program for mounting heifers that reached the optimal age for this procedure has led to an increase from 23 heads in the $1^{\text {st }}$ quarter to 31 in the $2^{\text {nd }}$ quarter. The expenditure for implementing these systems amounted to an initial investment of 11,000 lei, which includes training and operational programs and an annual subscription for maintenance of 1,000 lei. If we do a simulation for 12 future quarters, we observe a $9 \%$ increase of total profit for zootechnical compartment. Also we did an estimated profit linear simulation which we can observe bellow and estimate that profit at a point will decrease.

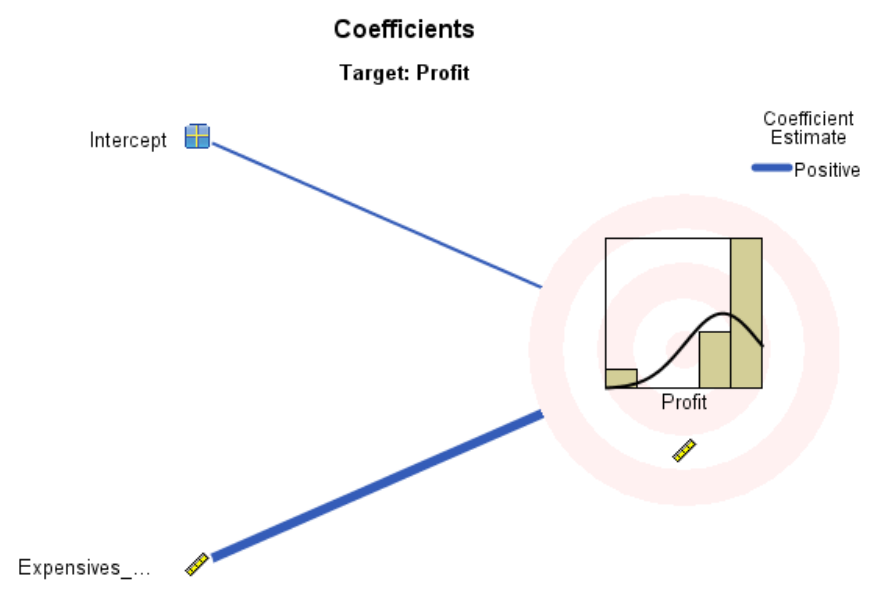

Figure 1: Estimated profit linear simulation

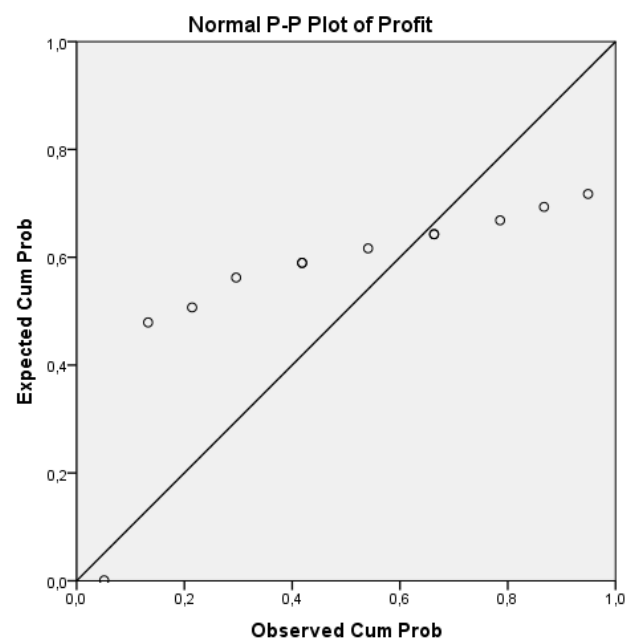

Figure 2: Increase of profit 


\section{Conclusions}

In conclusion, we can say that the implementation of modern management systems is a major concern for a large part of private entities in the livestock business and their implementation could change the satisfaction level and the perception that the staff has regarding all processes undertaken. It is normally to observe that at a point the profit will decrease all because new technology would be ready to implement.

Both public institutions and private entities of this type can benefit from a good quality applied management and good quality mentality in defining their mission, solving problems and obtaining results with these systems is a positive one.

The implementation objective is to develop a strong, open, fast and efficient relationship between all staff members of such an organization. We are also looking forward to future research in this area, which should emphasize better on how an investment upon certain management processes using modern techniques can generate a higher income for those organizations.

\section{References}

[1] Burduș E., Tratat de management - Ediția a II-a, Ed. Pro Universitaria, București, 2012

[2] Burduș E., Căprărescu G., Androniceanu A., Managementul schimbării organizaționale - Ediția a treia, Ed. Economică, București, 2008

[3] Kupritz, V.W., Cowell, E., Productive Management Communication; Journal Of Business

Communication; 48 (1): p. 54 - 82, 2011.

[4] Luk, S.Y., Questions of Ethics in Public Sector Management: The Case Study of Hong Kong; Public Personnel Management; 41 (2) p. 361 - 378, 2012.

[5] Matei L.,Management public, Ed.Economică,Bucureşti,2001

[6] Nedelea, A., Marketing în administraţia publică, Ed. Didactică şi Pedagogică, Bucureşti, 2006

[7] Research and development station for cattle from Arad, Bodrogului Street No 32 specific documents, interviewers, approvals. 